\title{
A Painful Symphony: The Presence of Overuse Syndrome in Professional Classical Musicians
}

\author{
Una Sinfonía Dolorosa: La Presencia del Síndrome \\ de Uso Excesivo en Músicos Clásicos Profesionales
}

\author{
Dusica L. Maric ${ }^{1}$; Marko Stojic ${ }^{2}$; Dusan M. Maric ${ }^{3}$; Sonja Susnjevic ${ }^{4}$; Dragana Radosevic ${ }^{1}$ \& Nikola Knezi ${ }^{1}$
}

MARIC, D. L.; STOJIC, M.; MARIC, D. M.; SUSNJEVIC, S.; RADOSEVIC, D. \& KNEZI, N. A painful symphony: The presence of overuse syndrome in professional classical musicians. Int. J. Morphol., 37(3):1118-1122, 2019.

SUMMARY: Musculoskeletal problems are common in instrumental musicians. Little is known about the factors that place musicians at risk, and the ways in which musicians can prevent these problems. Overuse syndrome is the most reported diagnosis among instrumental musicians suffering from playing related musculoskeletal injuries. The study group comprised 50 musicians employed in Symphony Orchestra of the Serbian National Theatre of Novi Sad. Out of the 50 musicians, 30 (60\%) are male and 20 (40\%) female. Higher frequencies of the presence of musculoskeletal symptoms were neck, region of trapezius, back, shoulder, wrist, hand and arm. A larger number of musicians $(81.8 \%)$ had perception of high demand of the profession. This investigation with professional classical musicians should show the music-medical interest.

KEY WORDS: Musicians; Overuse syndrome; Playing related musculoskeletal injuries; Back.

\section{INTRODUCTION}

Musculotendinous problems are common in instrumental musicians. The most common musculotendinous condition reported by authors in Performing Arts Medicine literature is overuse syndrome. This term is used to define pain for which no diagnosis can be made and which has been ascribed to occupational overuse (Palmer \& Cooper, 2006). Muscle-tendon unit is particularly subjected to overload. Repetitive strain injury is highly likely if musicians practice and use their arms all day at work. Musicians, dancers, and athletes are considered at risk for higher levels of stress, cognitive hearing problems and sleep disorders (Pereira et al., 2010).

Investigations of symphony orchestras found that 64 $\%$ to $76 \%$ of musicians were experiencing repetitive strain injury that affected their performance (Fry, 1986). Musculoskeletal complaints in musicians occur more frequently compared to the general working population, with lifetime prevalence reported up to even $93 \%$ (Kok et al., 2016). Common playing related musculoskeletal injuries (PRMI) of musicians include overuse problems, pain, weakness, stiffness, numbness, tingling, loss of muscular control and peripheral nerve entrapment syndromes (Zaza et al., 1998). These conditions typically affect the upper limbs, the neck, the back and the facial musculature. Several studies indicate an increasing number of musicians with occupational disorders and a need for treatment and consultation (Monaco et al., 2012; Schoeb \& Zosso, 2012). Although Performing Arts Medicine is a growing field, the health problems of musicians remain under recognized and under researched. Little is known about the factors that place musicians at risk, and the ways in which musicians can prevent these problems. Overuse and false technique, incorrect posture, stress and inadequate rest contribute to injuries that can cause the end of musicians careers. The prevalence of repetitive stress injury in musicians is such that primary treatment for repetitive stress injury must be prevention. The most effective treatment is education and implementation of healthy lifestyle habits.

This investigation with professional classical musicians should show the music-medical interest.

\footnotetext{
${ }^{1}$ Department of Anatomy, University of Novi Sad, Faculty of Medicine, Serbia.

${ }^{2}$ Faculty of Medicine,University of Novi Sad, Serbia.

${ }^{3}$ Department of Surgery, University of Novi Sad, Faculty of Medicine, Serbia.

${ }^{4}$ Department of Social Medicine and Health Statistics with Informatic, University of Novi Sad, Faculty of Medicine, Serbia.
} 


\section{MATERIAL AND METHOD}

Participants were 50 professional classical musicians of the Serbian National Theatre symphonic orchestra in Novi Sad. The study was approved by the Ethics Committee of the University of Novi Sad, Faculty of Medicine, Serbia.

Studied musicians acted in three different types of instruments: strings, woods, and keyboard. Participants were between 21 and 58 years old, and they have been playing their instruments between 15 an 50 years.

The musicians were asked to complete a questionnaire concerning socio-demographic characteristics, use of music instruments and the occurrence of musculoskeletal complaints in six body regions. Questions were related to musculoskeletal complaints over the last twelve months and at the time of the questionnaire (Kourinka et al., 1987). Musicians have answered the questionnaire under supervision of authors

We consider musculotendinous overuse to be any musculoskeletal problem, whether inflammatory or not, that appears to result from excessive use, presents with pain as the major symptom.

\section{RESULTS}

The study group was consisted of 50 musicians employed in Symphony Orchestra of the Serbian National Theatre of Novi Sad. $40 \%(n=20)$ of musicians were female, $60 \%(n=30)$ were male. The average age of musicians was 40 years, the youngest respondents were 21 , and the oldest 58 years old. 44 ( $88 \%$ ) musicians began to play instrument before the age of 10 , and at the time of the survey, study participant had been playing for more than 20 years. The average age of the musculosckeletal symptoms was 25.54 years.

Thirty $(60 \%)$ play the string instruments, while 10 (20\%) play wind instruments and keyboard. Other instruments were less represented (Fig. 1).

The majority of musculotendinous symptoms in these studies involved the neck, region of trapezius muscle, back, shoulder, wrist, hand and arm, and most of the musicians presented with a chief complaint of pain. A larger number of musicians $(81.8 \%)$ claimed that it had affected their performance.

Of the 50 musicians examined, $43(86 \%)$ can be classified as having problems with musculotendinous

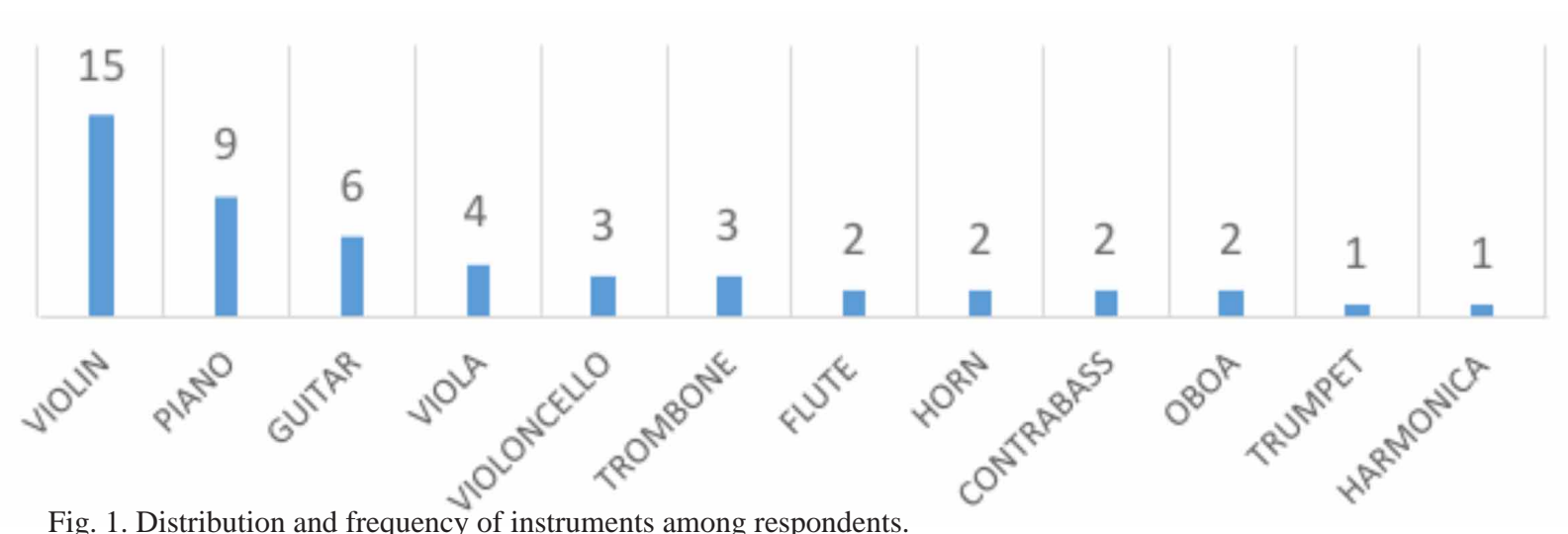

Fig. 1. Distribution and frequency of instruments among respondents.

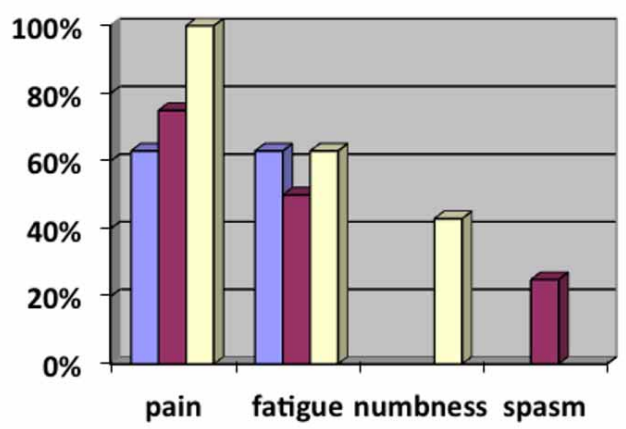

$\square$ Wind instruments

口Keyboard

$\square$ String instruments

Fig. 2. Presence of overuse symptoms in professional classical musicians. 
overuse. Players of string instruments 27 (90\%) reported current or recurring pain (Fig. 2). In this study pain was defined as chronic if it occurs repeatedly or continuously over a period of more than 3 months. The main localisation of pain for $26(96 \%)$ of the subjects was the upper part of the back, for $8(26 \%)$ of them the neck and for $4(15 \%)$ musicians was shoulders (Table I). Keyboard musicians 8 $(80 \%)$ also had the same problems. Pain was reported in 6 $(75 \%)$, fatigue $4(50 \%)$, and spasm in $2(25 \%)$ musicians (Fig. 2). The most common location of pain were upper back $7(87.5 \%)$, trapezius $5(62.5 \%)$ and wrist $2(25 \%)$ (Table I).

In the wind players neck pain was the most common location, followed by pain in lips and lower back (Table I).
Twenty five $(50 \%)$ musicians declared their regular playing practice to be on average 7 days per week,14 (28 $\%$ ) plays less than 30 hours a week. 26 (52\%) musicians take 15 minutes breaks during exercise.

For $27(54 \%)$ musicians the best way to reduce pain is to undergo special (medical) treatment, 22 (81\%) use medication, and $8(29 \%)$ use relaxation techniques. Only 2 (7\%) of respondents who applied for help did not have a change in condition, in $18(66 \%)$ respondents symptoms decreased, and 7 (26\%) musicians symptoms were completely gone.

Table I. Typical localization of pain in professional classical musicians

\begin{tabular}{lccccccc}
\hline Participants & Lips & Neck & Back & Upper limb & Shoulder & Wrist & Trapezius \\
& $\mathrm{n}(\%)$ & $\mathrm{n}(\%)$ & $\mathrm{n}(\%)$ & $\mathrm{n}(\%)$ & $\mathrm{n}(\%)$ & $\mathrm{n}(\%)$ \\
\hline $\begin{array}{l}\text { Wind } \\
\text { instruments } \\
\text { musicians }\end{array}$ & $4(50)$ & $5(63)$ & $4(50)$ & - & - & - \\
$\begin{array}{l}\text { Keyboard } \\
\text { musicians }\end{array}$ & - & - & - & $7(87,5)$ & - & $2(25)$ & $5(62,5)$ \\
$\begin{array}{l}\text { String } \\
\text { instruments } \\
\text { musicians }\end{array}$ & - & $8(26)$ & - & $26(96)$ & $4(15)$ & - & - \\
\hline
\end{tabular}

\section{DISCUSSION}

Professional musicians have a stressful career requiring long hours of practice. It is significant for musicians to determine if there are transforms or modifications of their instrument that could make it easier to play. Musicians who experience pain often continue practicing and playing, hoping that the pain will go away. Overuse syndrome is the most reported diagnosis among instrumental musicians suffering from PRMDs (Kok et al., 2013). Muscles that are fatigued become less efficient and less responsive; thus a demanding activity requires more force. This results in more fatigue and tension, like a vicious circle (Horvath, 2010). Continuing to play with pain will cause further damage. Bad posture, muscle tension in the neck, shoulders, and back can be the source of strain on spinal nerves.

The risk of musculoskeletal injury is apparently greater for women than men and greater for string players and keyboardists than other musicians (Zaza \& Farewell, 1997). The difference in risk between sexes may be due to anatomical and hormonal differences between women and men.
In relation to the age of the respondents, we can conclude that the symptoms of overload syndrome most commonly occur in the fourth decade of life, which are consistent with the work of Zaza \& Farewell.

Forty three $(86 \%)$ musicians were play through pain. The different groups of instruments provided a representation of the typical locations of pain. The strings were the group with the highest rate of pain in the upper limb, shoulder and neck. These results are similar with the work of Gasenzer et al. (2017) and Gohil et al. (2016).

Players of wind instruments show typical locations of pain as well. The neck is the most vulnerable body part, especially in high strings and flute players. The example of neck pain shows that size and weight of the instrument, especially wood wind and brass instruments, play an important part in the development of chronic pain. The reason for this is the characteristic body posture and the playing technique. Common diagnosis include muscle strains problems, especially distal to the elbow, with 
intrinsic muscles and extrinsic flexors involved (Dawson, 2002). Flute players may be affected by specific musculoskeletal problems directly related with their instrumental practice, such as lip muscle injury. An example of such an injury is rupture of the orbicularis oris, also known as Satchmo's syndrome (Cebriá i Iranzo et al., 2010). Flute players are more common to present inflammatory conditions, such as de Quervain's tenosynovitis at the wrist and trigger digits, although they may be affected by muscle strains problems too (Dawson).

In the keyboard players forearm pain was the most common location. The muscles of the upper limb are extremely stretched. The trapezius muscle region was also mentioned as a much affected body part, followed by pain in hands and wrists. These results suggest that the primary anatomical locations of PRMD in classical pianists differ from those in the jazz players. The most common symptoms of PRMD reported by Wood (2014) in the jazz pianists are overuse of shoulder, triceps and neck.

A study comparing the musculoskeletal symptoms of instrumental musicians with asymmetrical and symmetrical postures found that those with an asymmetrical playing posture, such as flautists, were significantly more likely to report musculoskeletal disorders of the back, neck and shoulder regions (Wahlstrom Edling \& Fjellman-Wiklund, 2009). These results showed correlations between instrument and pain location, and had trends similar to the study with Turkish musicians were physical exertion, and physical load were high in all the musicians, but mostly in viola players (Akel \& Düger, 2007).

Health care professional should represent an important stream to make aware musicians about PRMDs and pain management. Manchester \& Fleider (1991) have recommended taking rest breaks known as "periodization." Those following this advice would be expected to lessen the possibility of reporting PRMD. Breaks are the most effective injury prevention strategy. Farty five minutes to 1 hour is the maximum anyone should practice without taking a break; 25 to 30 minutes is often recommended.

In our semple only $2(7 \%)$ musicians did not improve their symptoms. These results showed the great success of the treatment of symptoms of overload syndrome, as quoted by Knishkowy and Lederman in their study (Knishkowry \& Lederman, 1986).

Correction of improper technique and increased rest during play are useful in the treatment of overuse symptoms (Lederman, 2003). It is necessary to educate young musicians about the im-portance of performing physical exercises regularly, since this may be a strategy used for prevention of the musculoskeletal system disorders (Nawrocka et al., 2014). According to a study by LeVine \& Irvine (1984), biofeedback therapy is used as a form of treatment and prevention, in an attempt to minimize unnecessary stress.

The medical profession is increasingly recognizing its responsibility to help performing artists in their fight against pain and disease and to treat them and their ailments in the most humane and effective ways possible.

\section{CONCLUSIONS}

The upper back and neck was the most frequent symptom site for musicians, and the primary symptom was pain. A larger number of musicians claimed that it had affected their performance. Many musicians react only when it is too late, when the process of developing an overuse syndrome or chronic pain has already started. Since the prevalence is high compared to the general population, research into effective interventions to prevent and treat musculoskeletal complaints among musicians is necessary.

MARIC, D. L.; STOJIC, M.; MARIC, D. M.; SUSNJEVIC, S.; RADOSEVIC, D. \& KNEZI, N. Una sinfonía dolorosa: la presencia del síndrome de uso excesivo en músicos clásicos profesionales. Int. J. Morpol., 37(3):1118-1122, 2019.

RESUMEN: Los problemas musculo-esqueléticos son comunes en los músicos instrumentales. Poco se sabe sobre los factores que ponen en riesgo a los músicos y las formas en que los ellos pueden prevenir estos problemas. El síndrome de uso excesivo es el diagnóstico más informado entre los músicos instrumentales que sufren lesiones musculo-esqueléticas relacionadas al uso de instrumentos musicales. El grupo de estudio estuvo compuesto por 50 músicos de la Orquesta Sinfónica del Teatro Nacional Serbio de Novi Sad. De los 50 músicos, $30(60 \%)$ eran hombres y $20(40 \%)$ mujeres. La frecuencia más alta de presencia de síntomas musculoesqueléticos se produjo en el cuello, músculo trapecio, espalda, hombro, muñeca, mano y brazo. Un mayor número de músicos $(81,8 \%)$ tuvo una percepción de alta demanda de la profesión. Esta investigación con músicos clásicos profesionales debería ser de interés médico-musical.

PALABRAS CLAVE: Músicos; Síndrome de uso excesivo; Uso de instrumentos; Lesiones musculoesqueléticas; Espalda. 


\section{REFERENCES}

Akel, S. \& Düger, T. Psychosocial risk factors of musicians in Turkey: use of the job content questionnaire. Med. Probl. Perform. Art., 22(4):147$52,2007$.

Cebriá i Iranzo, M. À.; Pérez-Soriano, P.; Camacho, C. I.; Belloch, S. L. \& Cortell-Tormo, J. M. Playing-related musculoskeletal disorders in woodwind, brass and percussion players: A review. J. Hum. Sport Exerc., 5(1):94-100, 2010.

Dawson, W. J. Upper-extremity problems caused by playing specific instruments. Med. Probl. Perform. Art., 17(3):135-40, 2002.

Fry, H. J. H. Incidence of overuse syndrome in the symphony orchestra. Med. Probl. Perform. Art., 1(2):51-55, 1986.

Gasenzer, E. R.; Klumpp, M. J.; Pieper, D. \& Neugebauer, E. A. M. The prevalence of chronic pain in orchestra musicians. Ger. Med. Sci., 15:Doc01, 2017.

Gohil, K.; Sheth, M. S. \& Vyas, N. Prevalence of playing related musculoskeletal disorders in musicians. Int. J. Ther. Appl., 32:100-3, 2016.

Horvath, J. Playing Less Hurt: An Injury Prevention Guide for Musicians. Milwaukee, Hal Leonard Books, 2010.

Knishkowy, B. \& Lederman, R. J. Instrumental musicians with upper extremity disorders: a follow up study. Med. Probl. Perform. Art., 1:859, 1986.

Kok, L. M.; Huisstede, B. M.; Voorn, V. M.; Schoones, J. W. \& Nelissen, R. G. The occurrence of musculoskeletal complaints among professional musicians: a systematic review. Int. Arch. Occup. Environ. Health, 89(3):373-96, 2016.

Kok, L. M.; Vlieland, T. P.; Fiocco, M. \& Nelissen, R. G. A comparative study on the prevalence of musculoskeletal complaints among musicians and non-musicians. B. M. C. Musculoskelet. Disord., 14:9, 2013.

Kourinka, I.; Jonsson, B.; Kilbom, A.; Vinterberg, H.; Biering-Sørensen, F.; Andersson, G. \& Jørgensen, K. Standardised Nordic questionnaires for the analysis of musculoskeletal symptoms. Appl. Ergon., 18(3):2237, 1987.

Lederman, R. J. Neuromuscular and musculoskeletal problems in instrumental musicians. Muscle Nerve, 27(5):549-61, 2003.

LeVine, W. R. \& Irvine, J. K. In vivo EMG biofeedback in violin and viola pedagogy. Biofeedback Self Regul., 9(2):161-8, 1984.

Manchester, R. A. \& Fleider, D. Further observations on the epidemiology of hand injuries in music students. Med. Probl. Perform. Art., 6:11-24, 1991.

Monaco, E.; Vicaro, V.; Catarinozzi, E.; Rossi, M. \& Prestigiacomo, C. Musculoskeletal diseases among musicians of the "teatro dell'Opera" of Rome. G. Ital. Med. Lav. Ergon., 34(2):158-63, 2012.

Nawrocka, A.; Mynarski, W.; Powerska, A.; Grabara, M.; Groffik, D. \& Borek, Z. Health-oriented physical activity in prevention of musculoskeletal disorders among young Polish musicians. Int. J. Occup. Med. Environ. Health, 27(1):28-37, 2014.

Palmer, K. T. \& Cooper, C. Work-related disorders of the upper limbo. Arthritis Res. Campaign, 10:1-7, 2006.

Pereira, E. F.; Teixeira, C. S.; Kothe, F.; Merino, E. A. D. \& Daronco, L. S. E. Percepção de qualidade do sono e da qualidade de vida de músicos de orquestra. Rev. Psiquiatr. Clín., 37(2):48-51, 2010.

Schoeb, V. \& Zosso, A. "You cannot perform music without taking care of your body": a qualitative study on musicians' representation of body and health. Med. Probl. Perform. Art., 27(3):129-36, 2012.

Wahlstrom Edling, C. \& Fjellman-Wiklund, A. Musculoskeletal disorders and asymmetric playing postures of the upper extremity and back in music teachers: a pilot study. Med. Probl. Perform. Art., 24(3):113-8, 2009.

Wood, G. C. Prevalence, risk factors, and effects of performance-related medical disorders (PRMD) among tertiary-trained jazz pianists in Australia and the United States. Med. Probl. Perform. Art., 29(1):37-45, 2014.
Zaza, C. \& Farewell, V. T. Musicians' playing-related musculoskeletal disorders: an examination of risk factors. Am. J. Ind. Med., 32(3):292300, 1997.

Zaza, C.; Charles, C. \& Muszynski, A. The meaning of playing-related musculoskeletal disorders to classical musicians. Soc. Sci. Med., 47(2):2013-23, 1998.

Corresponding author:

Assoc. Prof. Dusica L. Maric MD PhD

University of Novi Sad

Faculty of Medicine

Department of Anatomy

Novi Sad

SERBIA

Email: dusica.maric@mf.uns.ac.rs

Received: 13-09-2018

Accepted: $21-02-2019$ 